\title{
Thiazole- and Thiadiazole-Based Metal-Organic Frameworks and Coordination Polymers for Luminescent Applications
}

\author{
Giorgio Mercuri ${ }^{1}$, Giuliano Giambastiani ${ }^{1,2}{ }^{-1}$ and Andrea Rossin ${ }^{1, *(1)}$ \\ 1 Istituto di Chimica dei Composti Organometallici (ICCOM-CNR), Via Madonna del Piano 10, \\ 50019 Sesto Fiorentino, Italy; giorgio.mercuri@iccom.cnr.it (G.M.); giuliano.giambastiani@iccom.cnr.it (G.G.) \\ 2 Institute of Chemistry and Processes for Energy, Environment and Health (ICPEES), \\ UMR 7515 CNRS University of Strasbourg (UdS), 25, rue Becquerel, 67087 Strasbourg CEDEX 02, France \\ * Correspondence: a.rossin@iccom.cnr.it; Tel.: +39-055-522-5248
}

Received: 15 November 2019; Accepted: 12 December 2019; Published: 14 December 2019

\begin{abstract}
This mini-review focuses on the 2015-2019 literature survey of thiazole- and thiadiazole-containing Metal-Organic Frameworks (MOFs) and Coordination Polymers (CPs) exploited in the applicative field of luminescent sensing.
\end{abstract}

Keywords: thiazole; thiadiazole; metal-organic frameworks; coordination polymers; luminescence

\section{Introduction}

Chemical sensors, i.e., analytical tools that provide information about the chemical composition of the environment in which they are introduced, are based on a variety of transduction mechanisms (e.g., optic, electronic, optoelectronic). Luminescent materials release energy in the form of electromagnetic radiation in the visible region in response to external stimuli [1]. Recently, luminescent materials have gained the stage as chemical sensors [2], as luminescence is among the most desirable transduction mechanisms for its relative easiness of use, technical simplicity and broad adaptability [3].

Metal-organic frameworks (MOFs) are hybrid organic/inorganic 3D coordination polymers with open structures deriving from the self-assembly of poly(topic) ligands and metal ions or metal-based clusters [4]. In the past fifteen years, MOFs have emerged as a promising alternative to all inorganic materials (e.g., activated carbons and zeolites) in industrially and technologically relevant applications requiring porous compounds. As chemical sensors, luminescent MOFs possess a number of advantages over other luminescent materials. Analyte adsorption within MOF pores allows for its pre-concentration, increasing sensor sensitivity. Selectivity in MOFs can be achieved by tuning pore dimension and/or by proper functionalization of the linkers. Porosity allows for adsorption of chromophores which can be luminescent themselves or act as antennas, this enlarging the number of mechanisms beyond luminescence [5]. MOFs structure flexibility may lead to changes in the local coordination environment, hence in the emissive properties, upon guest adsorption [6]. Compared to amorphous luminescent compounds, MOFs possess well-defined crystal structures, which allows theoretical and experimental study of the sensing mechanisms at the molecular level. Finally, they are less expensive than other detection methods.

MOFs luminescence may have different origins [7-10]: ligand-based, metal-based, charge-transfer, or guest-induced (Figure 1). Linker-based luminescence is commonly found in MOFs containing conjugated ligands with extended $\pi$-delocalized carbo- or heterocycles that absorb in the visible or UV region, combined with metallic nodes made of metal ions in a $\mathrm{d}^{10}$ or $\mathrm{d}^{0}$ electronic configuration, such as $\mathrm{Zn}(\mathrm{II}), \mathrm{Cd}(\mathrm{II})$ or $\mathrm{Zr}(\mathrm{IV})$ (i.e., largely electronically inert ions) [10-12]. Metal-centered luminescence 
(phosphorescence) requires the presence of open-shell configuration metal ions. Therefore, it is mostly seen in MOFs containing f-elements as nodes [13], although some examples with $\mathrm{d}^{10}$ metal ions are also present in the literature [14]. Fluorescent ligands typically bear $\pi$-conjugated electrons which can give emissions upon irradiation. Signal transduction in luminescent MOFs normally takes place through emission quenching (more occasionally enhancement) after a guest adsorption. The strength of these effects depend on the nature of the host-guest interactions. In the most interesting cases, adsorbates induce a shift in the emission wavelength of the MOF emission. This type of signal transduction is inherently more attractive than simple quenching. If the emission band falls in the visible region, the marked evidence of the occurred guest capture is immediately observable as a color change at the naked eye.

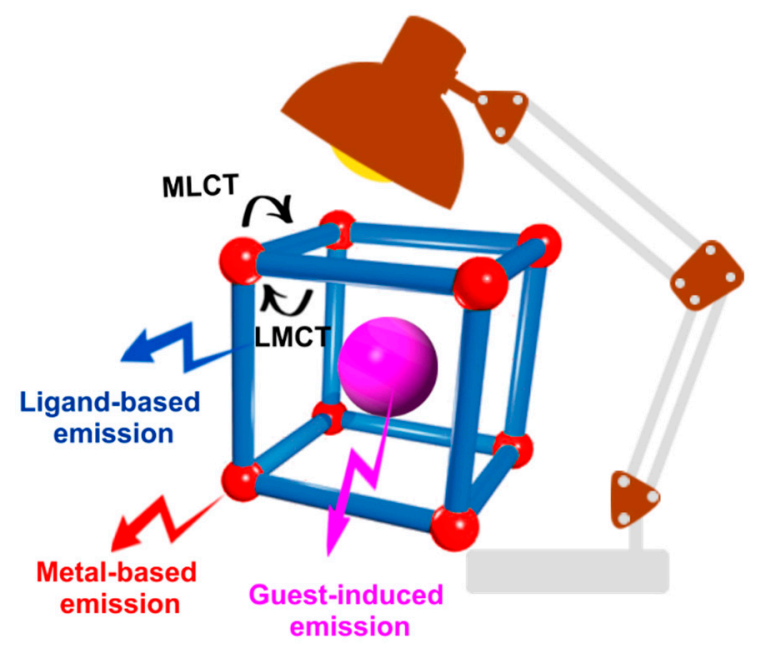

Figure 1. Pictorial representation of the mechanisms at the origin of MOFs luminescence.

More recently, the discovery and development of MIXMOFs (also known as Multivariate MOFs) [15-17] has opened new horizons in chemical sensing. The simultaneous presence of different linkers within a unique solid phase is useful for multiple sensing capability (multiplexing), i.e., the detection of different analytes with the same material combined with an extremely high sensitivity (low detection limits, Figure 2).

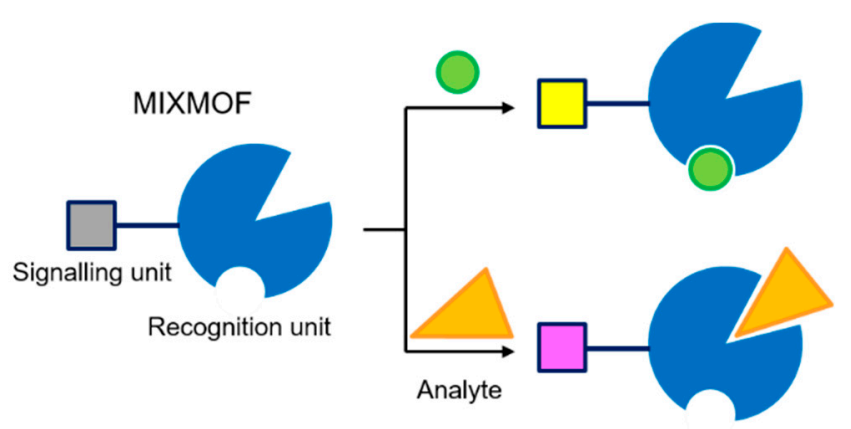

Figure 2. Pictorial representation of multiple sensing by MIXMOFs.

As for the target analytes of interest, MOFs have been proven to be efficient chemical sensors for gases [18-23], small molecules like solvents [24-27], amines [28,29], volatile organic compounds (VOCs) [30-32], explosives (nitroarenes) [33-35], bioactive compounds [36,37] and dyes [6]. Finally, detection of polluting metal ions (both cations and anions) in aqueous solutions is also a widely exploited application field [38-46].

The typical MOFs ligands belong to the classes of (aliphatic or aromatic) polycarboxylic acids and polydentate $\mathrm{N}$-heterocyclic bases (such as pyridines, imidazoles, pyrazoles and tetrazoles) $[47,48]$. 
The presence in the heterocycle of atoms different from nitrogen is relatively rare. In fact, there are much fewer examples of MOFs or CPs built with heterocycles containing oxygen, sulfur or selenium in their skeleton. Heteroatoms with pronounced differences in their relative Lewis basicity modify the electron density distribution within the linker and may show different coordination ability for metal ions used in the MOF synthesis when seen as alternative coordination sites. In addition, the abundance of electron-rich atoms in the linkers increases the number of weak non-covalent interactions (like hydrogen bonds or $\pi-\pi$ stacking) in the solid state, providing more thermally/chemically stable materials and generating fascinating crystalline scaffolds. Within the applicative context of luminescent sensing, organic light emitting diodes (OLEDs) and organic optoelectronics, $\pi$-conjugated heterocyclic compounds containing a sulfur atom like thiophene exhibit an extensive variety of optical, electrical and photoelectric applications. The introduction of an additional nitrogen atom in the linker should improve these features considerably. Consequently, in recent years there has been a growing interest in $(\mathrm{N}, \mathrm{S})$ containing heterocycles. Among the simplest and most naturally occurring $(\mathrm{N}, \mathrm{S})$ heterocycles there are thiazoles and thiadiazoles (Scheme 1 ). Thiazoles are intrinsically fluorescent $[49,50]$ and they can be found in several naturally occurring biomolecules like vitamin B1 (thiamine) or luciferin (the active component generating luminescence in fireflies). They have been exploited for the preparation of synthetic fungicides like thiabendazole, anti-inflammatory drugs like Meloxicam or in the fabrication of OLEDs and semiconductors [51,52]. More recently, their application as fully organic sensitizers in solar cells (DSSC) for energy applications has also started to appear in the literature [53,54].

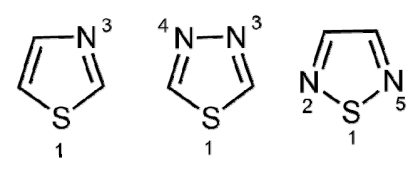

Scheme 1. 1,3-thiazole, 1,3,4-thiadiazole and 1,2,5-thiadiazole.

The preparation of thiazole-based MOFs/CPs (from ligand design to the polymer construction) is one of our main research activities [55-59]. In the last five years, there has been a significant boost in the interest on this specific topic. Following this interest and as an extension of a Highlight article published by our group in 2015 [60], in here we would like to present a 2015-2019 survey of thiazoleand thiadiazole-containing MOFs and CPs for applications in luminescence. The mini-review will be divided into two chapters: thiazole-based MOFs/CPs (Section 2) and thiadiazole-based MOFs/CPs (Section 3). We believe that this collection may be useful for other research groups who are actively working on the same research field worldwide as a reference work to find new inspiration and ideas for a better development of this intriguing and promising applicative field.

\section{Thiazole-Based MOFs and CPs as Luminescent Materials}

In the following Sections the literature survey is presented and classified according to both ligand type and publication year, moving from the oldest (2015) to the most recent (2019) examples within each category. A collective thiazole-based ligands scheme (Scheme 2) is reported here for the sake of clarity.

Thiazole, as such, has been exploited as a solvent in the synthesis of a series of lanthanide CPs from anhydrous $\mathrm{LnCl}_{3}$ and 1,2-bis(4-pyridyl)ethylene (dpe) under solvothermal conditions by the group of Müller-Buschbaum (Wurzburg, DEU) [61]. The obtained polymers of general formula $\left.\left[\mathrm{LnCl}_{3}(\mathrm{dpe}) \text { (thiazole }\right)_{2}\right] \infty$ are $1 \mathrm{D}$ or $2 \mathrm{D}$, and the connections between adjacent metal ions in the crystal structures are guaranteed by the dpe bridging linker. Thiazole always acts as an end-on (terminal) $\mathrm{N}$-bound ligand. Dpe was proved to be a suitable sensitizer for the photoluminescence of lanthanides in the near-infrared region (NIR) only: ligand-sensitized $4 f-4 f$ NIR emission is dominating for $\mathrm{Nd}(\mathrm{III})$, $\mathrm{Er}(\mathrm{III})$ and $\mathrm{Yb}(\mathrm{III})$. The same group has subsequently prepared the analogues containing the "saturated counterpart" of dpe, namely 1,2-bis(4-pyridyl)ethane (bpe), using the same synthetic approach [62]. Depending on the ligand content, assorted structures from 3D frameworks $\left\{\left[\mathrm{LnCl}_{3}(\mathrm{bpe})_{2}\right] \cdot \text { thiazole }\right\}_{\infty}$ 
$(\mathrm{Ln}=\mathrm{Ce}-\mathrm{Lu})$, to the $1 \mathrm{D}$-strand $\left[\mathrm{La}_{2} \mathrm{Cl}_{6}(\mathrm{bpe})_{2}(\text { thiazole })_{6}\right] \infty$ were obtained. The compounds exhibit a variety of luminescence properties and different phenomena. These included ligand-centered fluorescence, metal-centered $5 d-4 f / 4 f-4 f$ emission in the visible and the NIR range, and antenna effects via Dexter and Förster (FRET) energy transfer mechanisms (non-radiative processes with electron exchange). The obtained results proved that the linker bpe is also an excellent sensitizer for lanthanide emission, as observed for dpe. Finally, in 2017 the same research team replaced the pyridyl-based linkers with other $\mathrm{N}$-containing heterocycles: pyrazine (pyz) and pyrimidine (pym) [63], forming the compounds $\left.\left[\mathrm{Ln}_{2} \mathrm{Cl}_{6}(\mathrm{pyz}) \text { (thiazole }\right)_{6}\right] \infty$ and $\left.\left[\mathrm{Ln}_{2} \mathrm{Cl}_{6}(\mathrm{pym})_{2} \text { (thiazole }\right)_{4}\right] \infty(\mathrm{Ln}=\mathrm{Tb}, \mathrm{Er})$. The polymers with $\mathrm{Tb}$ and Er show intense luminescence with a strong sensitizer effect of the ligands that can be observed by dominant ligand excitation and exclusive metal emission for VIS and NIR.
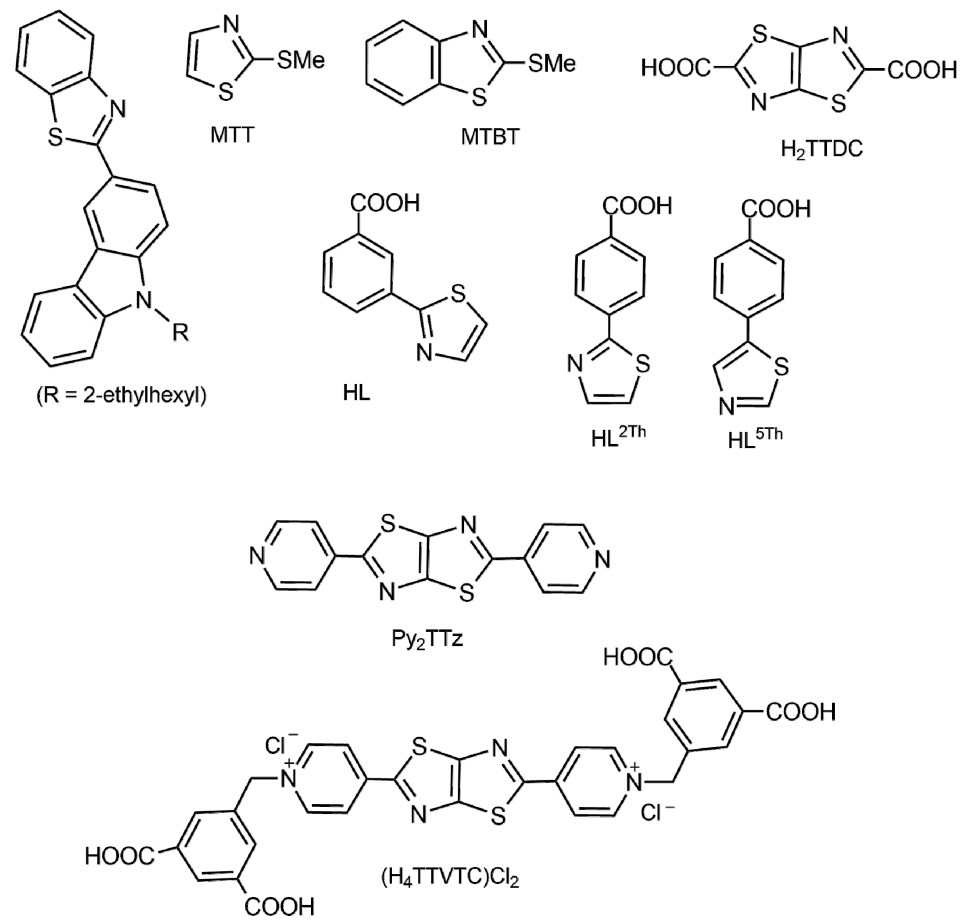

Scheme 2. Overview of the structures of the thiazole-containing ligands discussed in Section 2.

The group of Tang, Wang and co-workers (Kumming, CHN) prepared a novel red-emitting cationic iridium(III) coordination polymer using the thiazole-based ligand 2-(9-(2-ethylhexyl)-9H-carbazol-3-yl)benzo [d]thiazole (Scheme 2) and 4,4'-bipyridine (bipy). It can be efficiently excited by blue light of GaN chips when blended in YAG:Ce-GaN-based cold white LEDs at $0.1 \mathrm{wt} \%$ and $0.2 \mathrm{wt} \%$. The emission became neutral white light, and the collected results suggested that the coordination polymer is a promising red-emitting phosphor candidate for warm white LEDs [64].

Artem'ev and collaborators (Novosibirsk, RUS) exploited 2-(methylthio)thiazole (MTT) and 2-(methylthio)benzothiazole (MTBT) (Scheme 2) to prepare the corresponding copper(I) 1D CPs

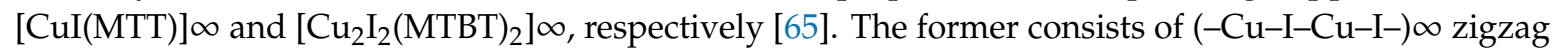
chains wherein the adjacent $\mathrm{Cu}$ atoms are bridged by the MTT ligand through the thiazole $\mathrm{N}$ and sulfide $\mathrm{S}$ atoms. In the latter, a planar $[\mathrm{Cu}(\mu-\mathrm{I})]_{2}$ dimeric core is supported by the two ligands in a N-monodentate manner. At ambient temperature, the former exhibits a weak yellow luminescence $(\lambda \max =570 \mathrm{~nm})$, while the latter emits in the deep-red region $(\lambda \max =705 \mathrm{~nm})$, thus representing a rare example of a $\mathrm{Cu}(\mathrm{I})$ coordination compound showing an emission in this color range. One year later, the same group started from the same ligands to prepare the $\mathrm{Ag}(\mathrm{I})$ analogues $\left[\mathrm{Ag}(\mathrm{MTT})\left(\mathrm{NO}_{3}\right)\right] \infty$ and $\left[\mathrm{Ag}_{2}(\mathrm{MTBT})_{2}\left(\mathrm{NO}_{3}\right)_{2}(\mathrm{MeCN})_{2}\right] \infty$ as layered 2D CPs exhibiting Ag...Ag interactions in the solid state [66]. The latter demonstrates dual emission behavior associated with simultaneous presence of 
high-energy and low-energy emission bands originated by $\mathrm{Ag}(\mathrm{I})$-perturbed singlet and triplet $\pi-\pi^{*}$ and $n-\pi^{*}$ intraligand transitions, respectively.

In recent years, our group has reported the preparation of $\mathrm{Zn}(\mathrm{II}) \mathrm{CPs}$ with different isomeric forms of (thiazolyl)benzoic acid. Four 1D coordination polymers have been prepared, starting from the organic linker $m$-(2-thiazolyl)benzoic acid (HL, Scheme 2), also combined with auxiliary ligands: $\left[\mathrm{Zn}_{2}(\mathrm{~L})_{4}\left(\mathrm{H}_{2} \mathrm{O}\right) \cdot 2(\mathrm{MeCN})\right] \infty,\left[\mathrm{Zn}_{2}(\mathrm{~L})_{3}\left(\mathrm{NO}_{3}\right)(\right.$ bipy $\left.)\right] \infty,\left[\mathrm{Zn}_{2}(\mathrm{~L})_{4}(\right.$ bipy $\left.)\right] \infty$, and $\left[\mathrm{Zn}_{2}(\mathrm{~L})_{4}(\right.$ bpe $\left.)\right] \infty$. In all species, the $\mathrm{Zn}_{2}$ (carboxylate) ${ }_{4}$ "paddle-wheel" dimer is the constituting inorganic node, where the carboxylate groups from $\mathrm{L}^{-}$are bridging two adjacent metal centers [56]. The polymeric nature stems from the auxiliary $\mathrm{N}$-donors that are shared by adjacent $\mathrm{Zn}_{2}$ dimers. The luminescent properties in aqueous solutions of $\left[\mathrm{Zn}_{2}(\mathrm{~L})_{4}(\right.$ bipy $\left.)\right] \infty$ and $\left[\mathrm{Zn}_{2}(\mathrm{~L})_{4}(\mathrm{bpe})\right] \infty$ have been examined. The $\mathrm{N}$ and $\mathrm{S}$ donors dangling from the thiazole rings in these polymers can engage into further supramolecular interactions with (acidic) metal cations, inducing a luminescence quenching after complexation. Their photophysical properties have been studied, in the presence and in the absence of $\mathrm{Hg}(\mathrm{II})$ ions. As expected, the electronic transitions observed are mainly ligand-centered, given the "closed shell" electronic configuration of the $\mathrm{Zn}(\mathrm{II})$ ion $\left(d^{10}\right)$ that bans any metal-to-ligand or ligand-to-metal charge transfer transitions. The complexation of an acidic cation like $\mathrm{Hg}(\mathrm{II})$ to the basic sites $(\mathrm{N})$ dangling from the ligand side-arms induces a luminescence quenching in both absorption and emission (Figure 3), along with a partial polymer aggregation in solution (as judged from the Dynamic Light Scattering results).

(a)

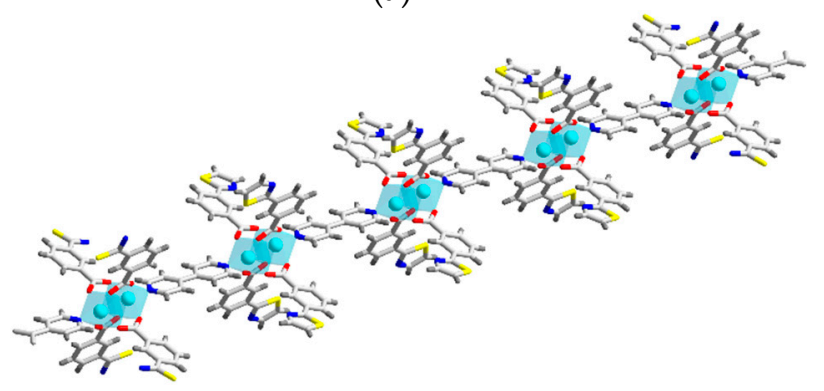

(c)

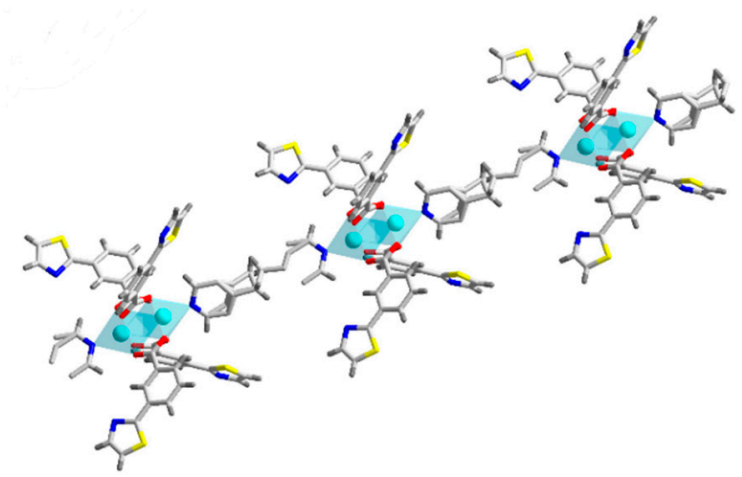

(b)

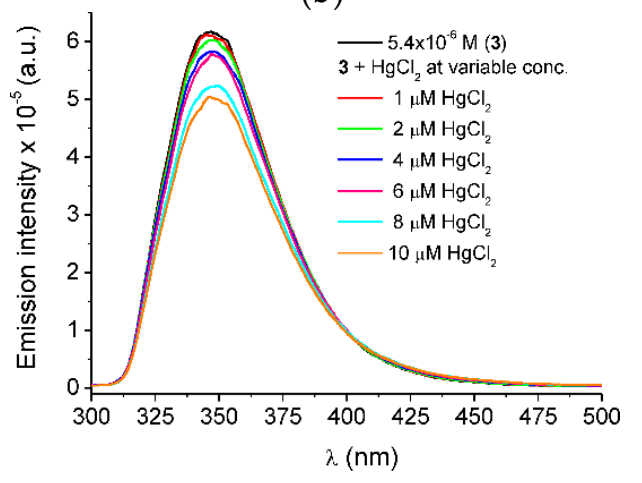

(d)

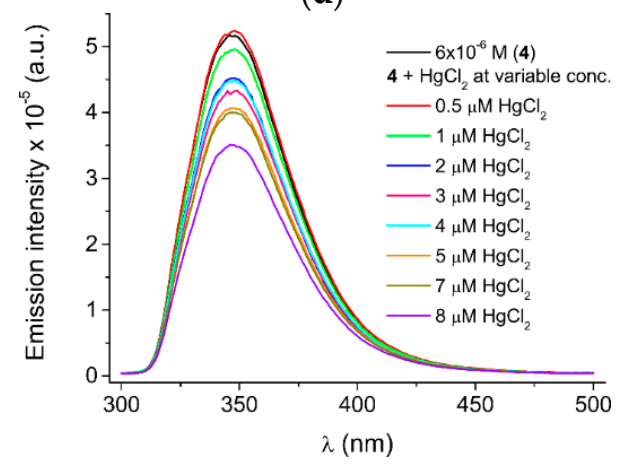

Figure 3. The $1 \mathrm{D}$ chain in the lattice of $\left[\mathrm{Zn}_{2}(\mathrm{~L})_{4}(\mathrm{bipy})\right] \infty(\mathbf{a})$ and $\left[\mathrm{Zn}_{2}(\mathrm{~L})_{4}(\mathrm{bpe})\right] \infty(\mathrm{c})$, along with the related emission spectra at variable $\mathrm{Hg}$ (II) concentrations in aqueous solutions (b,d). Taken from reference [56]. Reproduced with permission from Wiley VCH.

One year later, we moved to the home-made isomers $p$-(2-thiazolyl)benzoic acid $\left(\mathrm{HL}^{2 \mathrm{Th}}\right)$ and $p$-(5-thiazolyl)benzoic acid (HL ${ }^{5 T h}$, Scheme 2). Two coordination polymers of assorted dimensionality $(1 \mathrm{D}, 2 \mathrm{D})$ have been prepared, namely $\left[\mathrm{Zn}_{3}\left(\mathrm{~L}^{2 \mathrm{Th}}\right)_{4}(\mathrm{OH})_{2} \cdot 2\left(\mathrm{HL}^{2 \mathrm{Th}}\right)\right] \infty$ and $\left[\mathrm{Zn}\left(\mathrm{L}^{5 \mathrm{Th}}\right)(\mathrm{OAc})\right] \infty$, respectively [55]. The luminescent properties of both polymers have been analyzed in the solid 
state; they feature ligand-centered emissions at $\lambda=434 \mathrm{~nm}$ and $\lambda=427 \mathrm{~nm}$. These electronic transitions fall in the visible region, giving the samples a characteristic blue color under an ordinary UV lamp. The theoretical analysis of the electronic features of the ligands and related molecular orbitals reveals that the observed transitions are mainly of $\pi \rightarrow \pi^{*}$ nature, involving $\pi$ orbitals delocalized on both aromatic cycles. A significant (reversible) blue-shift of the emission maximum of ca. $60 \mathrm{~nm}$ from the visible to the UV region was observed for the $1 \mathrm{D}$ polymer (where the $\mathrm{N}$-thiazole donors are dangling from the polymeric chain) when suspended in water (Figure 4).

(a)

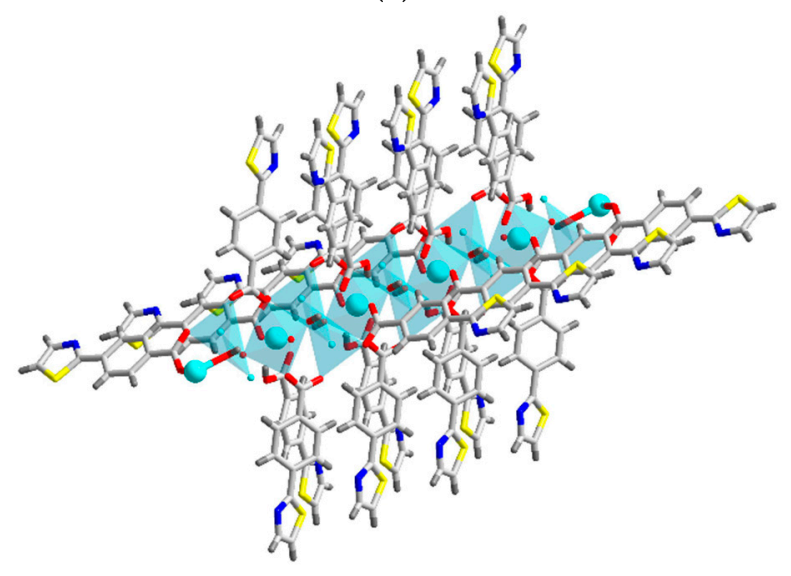

(b)

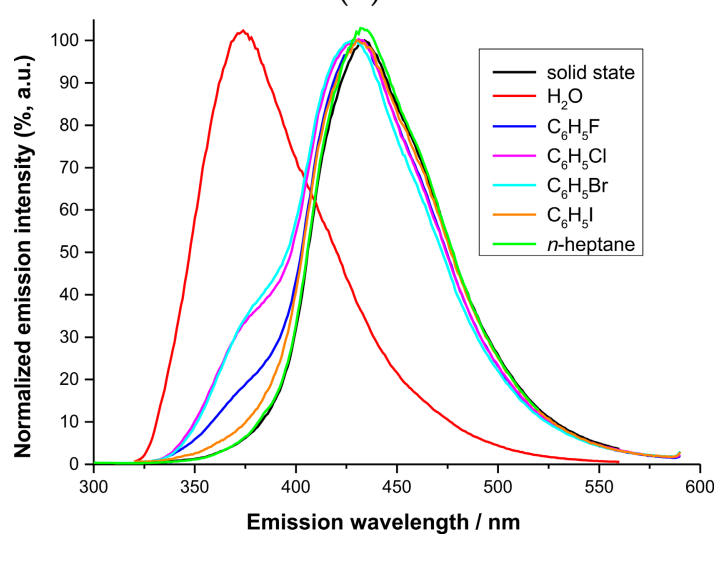

Figure 4. The 1D chain in the lattice of $\left[\mathrm{Zn}_{3}\left(\mathrm{~L}^{2 \mathrm{Th}}\right)_{4}(\mathrm{OH})_{2}\right] \infty(\mathbf{a})$ and its emission spectra when suspended in solvents with different polarity (b). Taken from reference [55]. Reproduced with permission from Wiley VCH.

Starting from 2018, the investigation on this field focused on a highly luminescent structural core: thiazolo [5,4-d] thiazole $\left(\mathrm{H}_{2}\right.$ TTDC), made of two fused 1,3-thiazole rings along the $\mathrm{C}(4)-\mathrm{C}(5)$ bond (Scheme 2). This chemical motif is planar, rigid and conjugated, thus representing an optimal fluorescent molecule. Indeed, it has been widely exploited in applications dealing with organic electronics and solar cells because of its appealing features [67-69]. Thiazolo [5,4- $d$ ] thiazole can be easily functionalized on $\mathrm{C}(2)$ and $\mathrm{C}(7)$ with coordinating groups suitable for the construction of MOFs and CPs. The group of Falcao et al. (Pernambuco, BRA) exploited thiazolo [5,4- $d$ ] thiazole-2,7-dicarboxylate (TTDC ${ }^{2-}$, Scheme 2) for the construction of lanthanide two-dimensional CPs of general formula [ $\operatorname{Ln}_{2}$ (TTDC) 3 $\left.8 \mathrm{H}_{2} \mathrm{O}\right] \infty(\mathrm{Ln}=\mathrm{La}, \mathrm{Ce}, \mathrm{Nd}, \mathrm{Sm}, \mathrm{Eu}, \mathrm{Gd})$ [70]. In these polymers, the rare Earths possess coordination number 9 , and the TTDC ${ }^{2-}$ ligand adopts different coordination modes, either terminal monodentate or $(\mathrm{N}, \mathrm{O})$-chelating bidentate through one $\mathrm{N}$ atom from the thiazole ring. This kind of behavior is frequently found in derivatives of thiazole-2- and thiazole-4-carboxylic acids [60]. Luminescence spectra for the $\mathrm{Nd}(\mathrm{III}), \mathrm{Sm}(\mathrm{III})$ and $\mathrm{Eu}(\mathrm{III})$ structures show the typical transitions of these ions, through the antenna effect promoted by the ligand. Since the simple thiazolo [5,4- $d$ ] thiazole-2,7-dicarboxylate is thermally labile, losing the carboxylic groups as $\mathrm{CO}_{2}$ at temperatures as low as $70^{\circ} \mathrm{C}$, TTDC ${ }^{2-}$ is not an ideal linker for solvothermal MOFs/CPs syntheses. Thus, alternative coordinating groups have been later attached to the end-carbon atoms of thiazolo $[5,4-d]$ thiazole. The most widely exploited molecule so far is 2,7-bis(4-pyridyl)thiazolo [5,4-d]thiazole (Py2TTz, Scheme 2). Du, Zang and co-workers (Zhengzhou, $\mathrm{CHN}$ ) prepared mixed-ligand MOFs (MIXMOFs) combining $\mathrm{Zn}$ (II) or Cd(II) with $\mathrm{Py}_{2} \mathrm{TTz}$ and terephtalic acid, obtaining pillared cubic structures of pcu topology: $\left[\mathrm{M}\left(\mathrm{Py}_{2} \mathrm{TTz}\right)(\mathrm{BDC}) \cdot 2(\mathrm{DMF})\right] \infty$, where $\mathrm{M}=\mathrm{Zn}$, $\mathrm{Cd} ; \mathrm{DMF}=\mathrm{N}, \mathrm{N}$-dimethylformamide and $\mathrm{BDC}^{2-}=$ terephtalate[71]. The pillar-layered frameworks consist of 2D sheets [constructed by ligand $\mathrm{BDC}^{2-}$ and "paddlewheel" secondary building units $\left.\mathrm{M}_{2}(\mathrm{COO})_{4}\right]$ and $\mathrm{Py}_{2} \mathrm{TTz}$ that pillars neighboring sheets. The frameworks are twofold-interpenetrated because of the long linker. Their fluorescence properties were investigated systematically. The results show that both MOFs display good fluorescent properties, which can be efficiently quenched by 
a trace amount of nitroaromatics 2,4,6-trinitrophenol and antibiotic nitrofurazone in water. The small limit of detection demonstrates that they can serve as good fluorescent sensors for trinitrophenol and nitrofurazone in aqueous environment. One year later, the same group has reported on the preparation of structural analogues containing variously substituted terephtalates and also with naphthalene-2,6-dicarboxylic acid ( $\mathrm{H}_{2} \mathrm{NDC}$ ) [72]. The presence of a linear dicarboxylate linker like $\mathrm{BDC}^{2-}$ (with the coordinating groups at $180^{\circ}$ with respect to each other) favors the formation of a multi-fold interpenetrated crystal lattice, while a V-shaped ligand like NDC ${ }^{2-}$ affords a 2D layered structure. All the synthesized compounds demonstrate structure-dependent luminescence in the solid state at room temperature, which are different from those of the pristine ligands. Compared to the emission peaks of the free ligands, the emission spectra of the MOF samples demonstrate different degrees of red shift. The nine MOFs prepared display structure-dependent emissions ranging from blue to blue-white and blue-green (Figure 5).

(a)

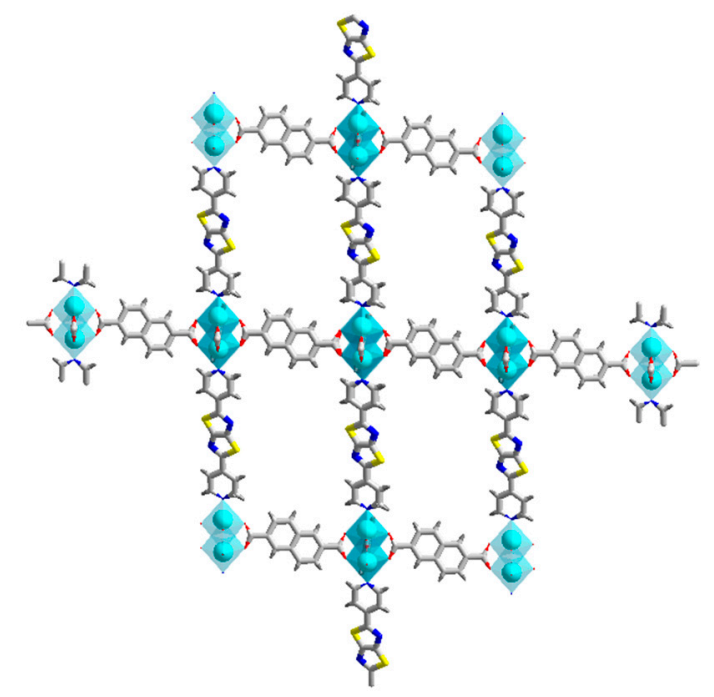

(b)

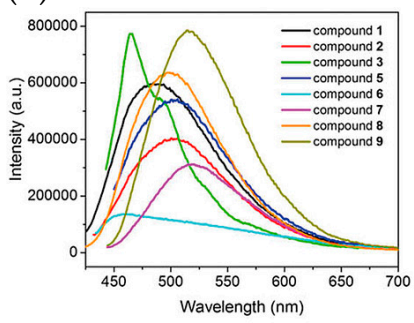

$\mathbf{a}$

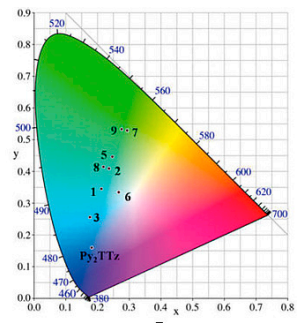

$\mathbf{b}$

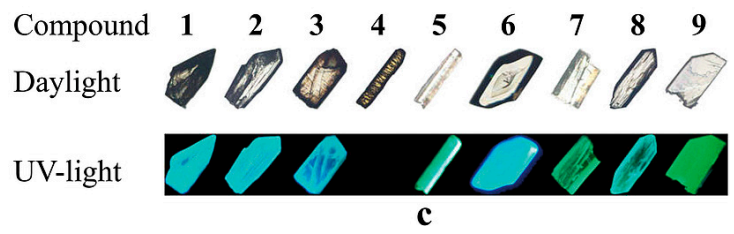

Figure 5. (a) Crystal structure of $\left[\mathrm{Zn}_{2}\left(\mathrm{Py}_{2} \mathrm{TTz}\right)(\mathrm{NDC})_{2}\right] \infty$; (b) Solid-state emission spectra, CIE chromaticity coordinates and crystal images under daylight and ultraviolet light of the family of compounds reported in Reference [72]. Reproduced with permission from Wiley VCH.

The group of Saha and co-workers (Clemson, USA) has studied the luminescent behavior of $\left[\mathrm{Zn}_{2}\left(\mathrm{Py}_{2} \mathrm{TTz}\right)(\mathrm{NDC})_{2}\right] \infty$ as such and in the presence of assorted transition metal cations [73]. NDC ${ }^{2-}$ struts serve as antenna chromophores and energy donors, while $\mathrm{Py}_{2} \mathrm{TTz}$ pillars act as complementary energy acceptors and light emitters. The highly ordered crystalline arrangement and the good overlap between their emission and absorption spectra enabled ligand-to-ligand Förster resonance energy transfer, allowing the MOF to display exclusively $\mathrm{Py}_{2} \mathrm{TTz}$-centric blue emission at $\lambda=410 \mathrm{~nm}$. In the presence of $\mathrm{Hg}(\mathrm{II})$, the photoluminescence of the MOF underwent a significant red shift to $450 \mathrm{~nm}$ followed by quenching, whereas other transition metal ions [Mn(II), Fe(II), Co(II), Ni(II), Cu(II) and $\mathrm{Cd}(\mathrm{II})]$ caused only fluorescence quenching but no shift. Consequently, $\left[\mathrm{Zn}_{2}\left(\mathrm{Py}_{2} \mathrm{TTz}\right)(\mathrm{NDC})_{2}\right] \infty$ can be considered an efficient $\mathrm{Hg}$ (II) luminescent sensor.

The group of Arici et al. (Eskiseir, TUR) prepared three novel Co(II) coordination polymers, formulated as $\left\{\left[\mathrm{Co}\left(\mu_{3}-\mathrm{ipa}\right)\left(\mathrm{Py}_{2} \mathrm{TTz}\right)\right] \cdot \mathrm{DMF}\right\}_{\infty}, \quad\left\{\left[\mathrm{Co}\left(\mu_{3}-\mathrm{fdc}\right)\left(\mathrm{Py}_{2} \mathrm{TTz}\right)\left(\mathrm{H}_{2} \mathrm{O}\right)\right] \cdot \mathrm{DMF}\right\}_{\infty}$ and $\left\{\left[\mathrm{Co}\left(\mu_{3}-\mathrm{tdc}\right)\left(\mathrm{Py}_{2} \mathrm{TTz}\right)\right] \cdot \mathrm{G}\right\} \infty$ (ipa $^{2-}=$ isophtalate, $\mathrm{fdc}^{2-}=$ furan-2,5-dicarboxylate, $\mathrm{tdc}^{2-}=$ thiophene-2,5-dicarboxylate, $G=$ guest solvent molecule) [74]. When the angles between the two carboxylate groups increase, the dimensionality of the compounds increases. Indeed, compound $\left\{\left[\mathrm{Co}\left(\mu_{3} \text {-ipa) }\left(\mathrm{Py}_{2} \mathrm{TTz}\right)\right] \cdot \mathrm{DMF}\right\}_{\infty}\right.$ (where the $-\mathrm{COO}^{-}$groups lie at $120^{\circ}$ with respect to each other) has a $2 \mathrm{D}$ layered structure, while the others (where the angle between the two carboxylates is around $145^{\circ}$ ) 
are 3D frameworks with pcu topology. The absorption bands of the polymers are similar to those of the corresponding organic constituents, mainly of $\pi-\pi^{*}$ nature.

In an intriguing variation on the theme, Gao et al. (Shanghai, CHN) designed an "extended viologen" organic linker through quaternization of the pyridine $\mathrm{N}$ atoms in $\mathrm{Py}_{2} \mathrm{TTz}$, forming the new tetracarboxylic acid 2,7-bis(1-(3,5-dicarboxylatobenzyl)pyridin-1-ium-4-yl)-thiazolo [5,4-d]thiazole (TTVTC ${ }^{2-}$, Scheme 2) [75]. Its incorporation into the $\mathrm{Zn}(\mathrm{II}) \mathrm{MOF}\left\{[\mathrm{Zn}(\mathrm{TTVTC})] \cdot 4 \mathrm{H}_{2} \mathrm{O}\right\} \infty$ produced a highly water-stable material that acts as an efficient and recyclable sensor for the detection of $\mathrm{Cr}(\mathrm{VI})$ in aqueous solutions. Extended viologen compounds have been shown to be strongly fluorescent; indeed, $\left[\mathrm{H}_{4}\right.$ TTVTC $] \mathrm{Cl}_{2}$ shows strong cyan emission under UV light $(365 \mathrm{~nm})$, and the solid-state fluorescence spectrum shows an emission band centered at $485 \mathrm{~nm}$. The related $\mathrm{Zn}-\mathrm{MOF}$ also shows strong fluorescence, the color becoming yellow-green and the emission maximum shifting to $524 \mathrm{~nm}$. The fluorescence of the aqueous dispersions was almost completely quenched by $\mathrm{K}_{2} \mathrm{CrO}_{4}$ and $\mathrm{K}_{2} \mathrm{Cr}_{2} \mathrm{O}_{7}$. By contrast, many other anions at the same concentration did not have significant effects (Figure 6).

(a)

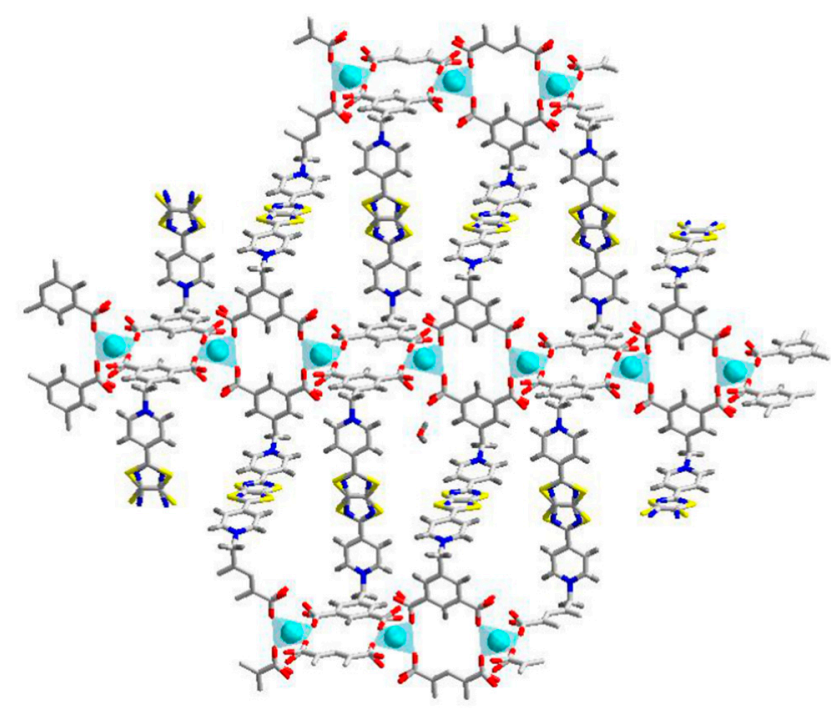

(b)
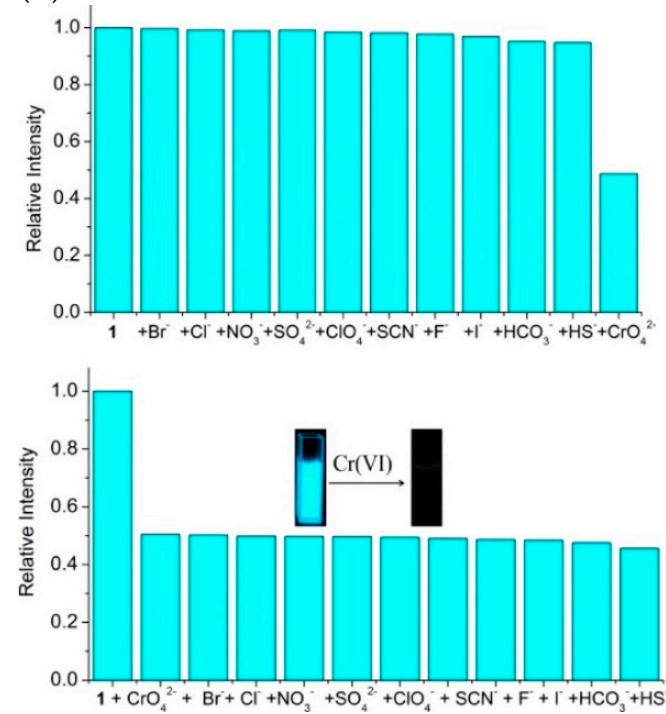

Figure 6. (a) Crystal structure of $\left\{[\mathrm{Zn}(\mathrm{TTVTC})] \cdot 4 \mathrm{H}_{2} \mathrm{O}\right\}_{\infty}$; (b) Its relative luminescent intensity by successively adding anions. The inset shows the visual fluorescence quenching by $\mathrm{CrO}_{4}{ }^{2-}$ or $\mathrm{Cr}_{2} \mathrm{O}_{7}{ }^{2-}$. Adapted with permission from Reference [75]. Copyright 2019. American Chemical Society.

\section{Thiadiazole-Based MOFs and CPs as Luminescent Sensors}

For thiadiazole, the two different isomers 1,3,4-thiadiazole and 1,2,5-thiadiazole will be discussed together within this Section. As for thiazole, Scheme 3 collects the chemical structures of the thiadiazole-based organic ligands of this paragraph.

In 2015, Wang and collaborators (Urumqi, CHN) reported on the synthesis of $\mathrm{Cu}$ (II) and $\mathrm{Cd}$ (II) CPs with different dimensionality (either 1D chains or 2D sheets) built with the 1,3,4-thiadiazole-containing isomeric linkers $\mathrm{L}^{1}, \mathrm{~L}^{2}$ and $\mathrm{L}^{3}$ (Scheme 3) [76]. The emission spectra of $\mathrm{L}^{3}$ and its $\mathrm{Cd}(\mathrm{II}) 2 \mathrm{D}$ polymer $\left[\mathrm{Cd}_{2}\left(\mathrm{~L}_{3}\right)_{3}\left(\mathrm{NO}_{3}\right)_{4}\left(\mathrm{H}_{2} \mathrm{O}\right)_{2}\right] \infty$ in the solid state at room temperature were investigated. $\mathrm{L}^{3}$ exhibits a weak blue fluorescent emission band around $410 \mathrm{~nm}$ upon excitation at $350 \mathrm{~nm}$, while the $\mathrm{Cd}$ (II) polymer exhibits an intense blue fluorescent emission band around $465 \mathrm{~nm}$. 

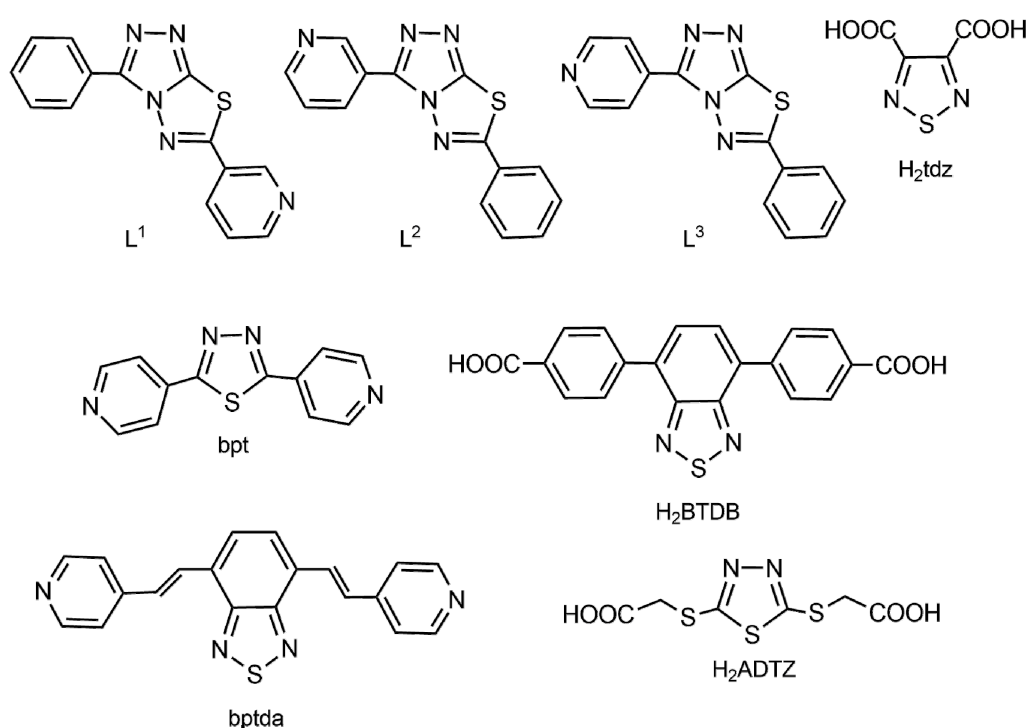<smiles>O=C(O)CSc1nnc(SCC(=O)O)s1</smiles>

Scheme 3. Overview of the structures of the thiadiazole-containing ligands discussed in Section 3.

The insertion of two 4-pyridyl units on $C(2)$ and $C(5)$ of 1,3,4-thiadiazole gives the neutral bridging linker bpt $=2,5$-bis(4-pyridyl)-1,3,4-thiadiazole (Scheme 3). This spacer has been exploited in 2016 by Ma and co-workers (Luoyang, $\mathrm{CHN}$ ) for the construction of a Cd(II) MOF with general formula $\left[\mathrm{Cd}_{2}(\mathrm{pam})_{2}(\mathrm{bpt})_{2}\left(\mathrm{H}_{2} \mathrm{O}\right)\right] \infty \cdot\left(\mathrm{pam}^{2-}=\right.$ pamoic acid, a dimer of naphthalenecarboxylic acid) [77]. Its fluorescent properties in the solid state indicate that this MOF may be a potential green-light-emitting material. In fact, the MOF gives a sharp fluorescent emission peak in the green region with a maximum at $\lambda=517 \mathrm{~nm}$, displaying a large red shift relative to those of free ligands $(472 \mathrm{~nm}$ and $385 \mathrm{~nm}$ for pamoic acid and bpt, respectively). More recently, the same bpt spacer combined with 5-aminoisophtalic acid ( $\mathrm{H}_{2}$ aiph) has been used by the team of $\mathrm{Bi}$, Fan and co-workers (Qingdao, $\mathrm{CHN}$ ) to build a Ni(II) MOF with general formula [Ni(aiph) $\left.(\mathrm{bpt})\left(\mathrm{H}_{2} \mathrm{O}\right)\right] \infty$ [78]. Rhodamine $\mathrm{B}$, methylene violet and methylene blue are the most common organic dyes in waste water. In this work, the nickel MOF was used to degrade aqueous solution containing these dyes under UV irradiation. After $90 \mathrm{~min}$ of irradiation, $89.5 \%$ of methylene blue, $84.7 \%$ of methylene violet and $76.4 \%$ of rhodamine B were decomposed in the presence of the MOF, showing an excellent photocatalytic performance in pollutants degradation, even if it has been found that the initial concentration and the catalysts loading both significantly influenced the degradation efficiency.

A new, strongly luminescent $\mathrm{Zr}(\mathrm{IV})$-based metal-organic framework (MOF) material having a UiO-68 ( $\mathrm{UiO}=$ University of Oslo $)$ framework topology and incorporating the $\pi$-conjugated, thiadiazole-functionalized $\mathrm{H}_{2} \mathrm{BTDB}$ ligand $\left(\mathrm{H}_{2} \mathrm{BTDB}=\right.$ 4,4'-(benzo[c][1,2,5]thiadiazole-4,7-diyl)dibenzoic acid, Scheme 3) was synthesized under solvothermal conditions in DMF by the group of Biswas (Assam, IND) [79]. The MOF has minimal formula $\left[\mathrm{Zr}_{6} \mathrm{O}_{4}(\mathrm{OH})_{4}(\mathrm{BTDB})_{6}\right] \cdot 8 \mathrm{H}_{2} \mathrm{O} \cdot 6 \mathrm{DMF}$. It showed an emission band centred at $510 \mathrm{~nm}$ upon excitation at $370 \mathrm{~nm}$, assigned to a $\pi-\pi^{*}$ intraligand transition. Its emission band is slightly blue-shifted and the fluorescence intensity enhanced by $69 \%$, as compared to the pristine organic ligand. The thermally activated form of the compound (after crystallization solvent removal) showed a selective sensing behavior towards 2,4,6-trinitrophenol (commonly known as picric acid), even in the presence of other potentially competing nitroaromatic explosive compounds. The highest fluorescence quenching ability of trinitrophenol can be attributed to both energy and electron transfer processes as well as electrostatic interactions between the hydroxyl group of trinitrophenol and the Lewis basic N-donor sites of the thidiazole-based ligand. In 2019, the same MOF has also been exploited by Eddaoudi and co-workers (KAUST, SAU) for the detection of amines in ultra-low traces (via fluorescence turn-on) in aqueous solutions [80]. This extremely powerful action is driven by hydrogen bonding interactions between the linker and the hosted amines. This observation is supported by density 
functional theory (DFT) calculations, which clearly corroborate the suppression of the twisting motion of the benzo[c] $[1,2,5]$ thiadiazole core in the presence of the amine guest, reducing significantly the non-radiative recombination pathways and subsequently, enhancing the emission intensity (Figure 7).

(a)

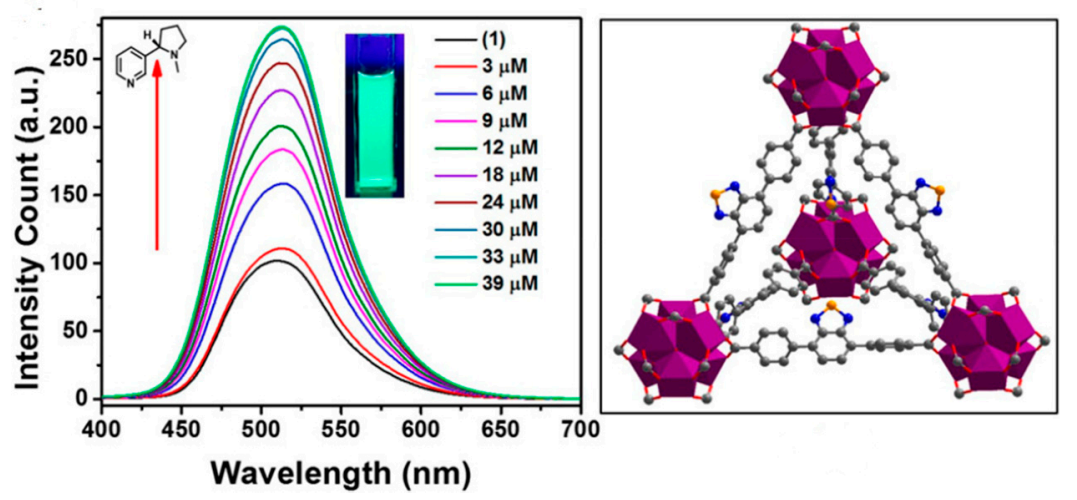

(b)
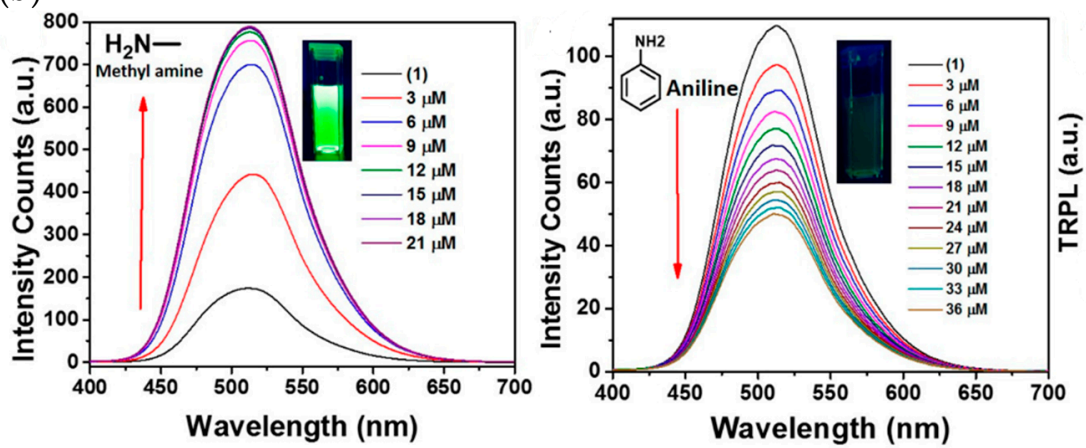

Figure 7. (a) The increase in fluorescence of $\left[\mathrm{Zr}_{6} \mathrm{O}_{4}(\mathrm{OH})_{4}(\mathrm{BTDB})_{6}\right] \infty$ upon addition of $3 \mu \mathrm{M}$ nicotine, and its chemical structure. (b) Fluorescence intensity of an aqueous suspension of the MOF upon addition of $3 \mu \mathrm{M}$ of methylamine or aniline $\left(\lambda_{\max }=515 \mathrm{~nm}\right)$. Reproduced with permission from Reference [80]. Copyright 2019. American Chemical Society.

The same benzo[c][1,2,5]thiadiazole central motif decorated by different coordinating side-arms has been prepared by Yang and Zhao (Tianjin, CHN). The coordinating ends are now 4-pyridyl groups, in the tailor-made linker 4,7-bis((E)-2-(pyridin-4-yl)vinyl)benzo [2,1,3]thiadiazole (bptda, Scheme 3) [81]. This ligand, in diverse stereochemical conformations around the $C=C$ double bonds present on its side-arms, has been combined with assorted dicarboxylic acids of variable bend angles to create four different $\mathrm{Zn}$ (II) MOFs. The main emission peak of the ligand, and also of the related MOFs, fall around $\lambda=560 \mathrm{~nm}$. The functionalization effect of thiadiazole groups on the optical absorption and visible-light-driven photocatalytic degradation of rhodamine B, methylene blue and crystal violet has been investigated, showing promising applications as dye degradation materials.

A 2D Cd(II) coordination polymer containing the 2,5-(s-acetic acid)dimercapto-1,3,4-thiadiazole $\left(\mathrm{H}_{2} \mathrm{ADTZ}\right.$, Scheme 3) ligand has been published by the group of Wang (Jinzhou, CHN): $\left[\mathrm{Cd}(\mathrm{bmbpd})_{0.5}(\mathrm{ADTZ})\left(\mathrm{H}_{2} \mathrm{O}\right)\right] \infty$, where bmbpd = $N, N^{\prime}$-bis(4-methylenepyridin-4-yl)-1,4-benzenedicarboxamide [82]. Its photoluminescent behavior in the presence of assorted organic solvents showed that it can be a good luminescent sensor (through emission quenching) for ethanol; furthermore, among the scrutinized samples it showed the best catalytic activity in methylene blue photodegradation (60\%).

The heterocyclic fluorogenic linker 1,2,5-thiadiazole-3,4-dicarboxylate $\left(\mathrm{H}_{2} \mathrm{tdz}\right.$, Scheme 3) offering diverse coordination modes has been utilized to synthesize two 3D metal organic frameworks, $[\mathrm{Cd}(\mathrm{tdz})($ bipy) $] \infty$ and $[\mathrm{Cu}(\mathrm{tdz})($ bipy) $] \infty$, by the research team of Mandal (Mohali, IND) [83]. Owing to 
its excellent stability in water, the photoluminescence spectrum of the $\mathrm{Cd}(\mathrm{II})$ polymer was studied in water. It exhibits a very strong emission intensity and is therefore considered a suitable material for sensing studies. The exposed nitrogen atoms in the $\mathrm{tdz}^{2-}$ linker are the preferential interaction sites with the hydroxy-containing nitro-aromatic explosives 2,4,6-trinitrophenol, 2,4-dinitrophenol and 4-nitrophenol. Indeed, the trend of increasing quenching efficiency ( $96 \%$ for the trinitrophenol and $\sim 90 \%$ for the others) is observed in accordance with the increase in the acidity of the hydroxyl proton of the nitro-explosives (in turn related to the increase in the number of electron-withdrawing nitro groups).

\section{Conclusions and Perspectives}

It is well known that luminescent MOFs show great promise as various types of sensors owing to their remarkable structural diversity and tunable luminescent properties. This field of investigation is still open to new contributions in terms of ligand design and MOF construction. Generally speaking, linkers containing multiple exposed basic sites ( $\mathrm{N}$ atoms of heterocycles in particular) are particularly useful to prepare porous luminescent MOFs with high sensing capability towards guests with protic groups, through the switch of $\mathrm{N} \cdots \mathrm{H}$ hydrogen bonding interactions. In the specific case of thiazoles and thiadiazoles, the presence of the sulfur atom is also useful to promote soft acid-soft base interactions with heavy metal polluting cations like $\mathrm{Hg}(\mathrm{II}), \mathrm{Cd}(\mathrm{II}), \mathrm{Pb}(\mathrm{II})$, thus creating optimal luminescent sensors for these pollutants in aqueous solutions. A future research direction in this area may be represented by the tailored synthesis of polycyclic rigid aromatic linkers containing more than one thiazole and/or thiadiazole rings. Subsequently, the preparation of highly porous and water-stable MOFs with these linkers is mandatory, representing the second step towards the obtainment of an optimal solid-state sensor. The main hurdle in this synthetic step is represented by the very low linker solubility in the solvent used for the MOF synthesis (normally polar and high-boiling solvents like DMF or $\mathrm{N}, \mathrm{N}$-diethylformamde (DEF)). The higher the linker conjugation degree and molecular weight, the lower the solubility. A promising approach to solve this problem is represented by mechanochemical (solvent-free) synthesis, through ball milling of the neat reagents. To save experimental efforts, preliminary theoretical screening of the sensor-substrate ensemble can help in predicting host-guest interactions in silico and improve the design of the final MOF structure, as already observed in the field of $\mathrm{CO}_{2}$ storage and utilization [84]. As for the metal type, the best candidate is surely zirconium, since the octahedral $\left[\mathrm{Zr}_{6}\right]$ metallic node present in all members of the "UiO family" generates MOF structures featured by high chemical and thermal stability. At present, our research group is proceeding in this direction for the obtainment of well-performing MOFs in the exciting field of luminescent sensing.

Author Contributions: Conceptualization, A.R.; literature data collection and curation, G.M., G.G. and A.R.; writing-original draft preparation, A.R.; writing_review and editing, G.M. and G.G.; funding acquisition, A.R. and G.G.

Funding: Our research on synthesis of thiazole-based MOFs and applications in gas storage and luminescent sensing is funded by the 2018-2021 bilateral CNR-RFBR project of the Italian National Research Council (CNR) and by the Italian MIUR through the PRIN 2017 Project Multi-e (20179337R7) "Multielectron transfer for the conversion of small molecules: an enabling technology for the chemical use of renewable energy". G.G. thanks the TRAINER project (Catalysts for Transition to Renewable Energy Future) Ref. ANR-17-MPGA-0017 for financial support.

Conflicts of Interest: The authors declare no conflict of interest.

\section{References}

1. Blasse, G.; Grabmaier, B. Luminescent Materials; Springer: Berlin, Germany, 1994.

2. Bünzli, J.-C.G. Lanthanide Luminescence for Biomedical Analyses and Imaging. Chem. Rev. 2010, 110, 2729-2755. [CrossRef] [PubMed]

3. You, L.; Zha, D.; Anslyn, E.V. Recent Advances in Supramolecular Analytical Chemistry Using Optical Sensing. Chem. Rev. 2015, 115, 7840-7892. [CrossRef] [PubMed] 
4. $\quad$ Batten, S.R.; Champness, N.R.; Chen, X.-M.; Garcia-Martinez, J.; Kitagawa, S.; Öhrström, L.; O'Keeffe, M.; Suh, M.P.; Reedijk, J. Terminology of Metal-Organic Frameworks and Coordination Polymers (Iupac Recommendations 2013). Pure Appl. Chem. 2013, 85, 1715-1724. [CrossRef]

5. Cui, Y.; Yue, Y.; Qian, G.; Chen, B. Luminescent Functional Metal-Organic Frameworks. Chem. Rev. 2012, 112, 1126-1162. [CrossRef] [PubMed]

6. Ye, J.-W.; Zhou, H.-L.; Liu, S.-Y.; Cheng, X.-N.; Lin, R.-B.; Qi, X.-L.; Zhang, J.-P.; Chen, X.-M. Encapsulating Pyrene in a Metal-Organic Zeolite for Optical Sensing of Molecular Oxygen. Chem. Mater. 2015, 27, 8255-8260. [CrossRef]

7. Zhang, Y.; Yuan, S.; Day, G.; Wang, X.; Yang, X.; Zhou, H.-C. Luminescent Sensors Based on Metal-Organic Frameworks. Coord. Chem. Rev. 2018, 354, 28-45. [CrossRef]

8. Lustig, W.P.; Mukherjee, S.; Rudd, N.D.; Desai, A.V.; Li, J.; Ghosh, S.K. Metal-Organic Frameworks: Functional Luminescent and Photonic Materials for Sensing Applications. Chem. Soc. Rev. 2017, 46, 3242-3285. [CrossRef]

9. Yi, F.; Chen, D.; Wu, M.; Han, L.; Jiang, H.-L. Chemical Sensors Based on Metal-Organic Frameworks. ChemPlusChem 2016, 81, 675-690. [CrossRef]

10. Allendorf, M.D.; Bauer, C.A.; Bhakta, R.K.; Houk, R.J.T. Luminescent Metal-Organic Frameworks. Chem. Rev. 2009, 38, 1330-1352. [CrossRef]

11. Cepeda, J.; Rodríguez-Diéguez, A. Tuning the Luminescence Performance of Metal-Organic Frameworks Based on $d^{10}$ Metal Ions: From an Inherent Versatile Behaviour to their Response to External Stimuli. CrystEngComm 2016, 18, 8556-8573. [CrossRef]

12. Barbieri, A.; Accorsi, G.; Armaroli, N. Luminescent Complexes Beyond the Platinum Group: The $d^{10}$ Avenue. Chem. Commun. 2008, 2185-2193. [CrossRef] [PubMed]

13. Cui, Y.; Chen, B.; Qian, G. Lanthanide Metal-Organic Frameworks for Luminescent Sensing and Light-Emitting Applications. Coord. Chem. Rev. 2014, 273-274, 76-86. [CrossRef]

14. San Sebastian, E.; Rodríguez-Diéguez, A.; Seco, J.M.; Cepeda, J. Coordination Polymers with Intriguing Photoluminescence Behavior: The Promising Avenue for Greatest Long-Lasting Phosphors. Eur. J. Inorg. Chem. 2018, 2155-2174. [CrossRef]

15. Jiao, J.; Gong, W.; Wu, X.; Yang, S.; Cui, Y. Multivariate Crystalline Porous Materials: Synthesis, Property and Potential Application. Coord. Chem. Rev. 2019, 385, 174-190. [CrossRef]

16. Du, M.; Li, C.-P.; Liu, C.-S.; Fang, S.-M. Design and Construction of Coordination Polymers with Mixed-Ligand Synthetic Strategy. Coord. Chem. Rev. 2013, 257, 1282-1305. [CrossRef]

17. Lescouet, T.; Kockrick, E.; Bergeret, G.; Pera-Titus, M.; Aguado, S.; Farrusseng, D. Homogeneity of Flexible Metal-Organic Frameworks Containing Mixed Linkers. J. Mater. Chem. 2012, 22, 10287-10293. [CrossRef]

18. Travlou, N.L.A.; Singh, K.; Rodriguez-Castellon, E.; Bandosz, T.J. Cu-BTC MOF-Graphene-Based Hybrid Materials as Low Concentration Ammonia Sensors. J. Mater. Chem. A 2015, 3, 11417-11429. [CrossRef]

19. Desai, A.V.; Samanta, P.; Manna, B.; Ghoh, S.K. Aqueous Phase Nitric Oxide Detection by an Amine-Decorated Metal-Organic Framework. Chem. Commun. 2015, 51, 6111-6114. [CrossRef]

20. Gassensmith, J.J.; Kim, J.Y.; Holcroft, J.M.; Farha, O.K.; Stoddart, J.F.; Hupp, J.T.; Jeong, N.C. A Metal-Organic Framework-Based Material for Electrochemical Sensing of Carbon Dioxide. J. Am. Chem. Soc. 2014, 136, 8277-8282. [CrossRef]

21. Cui, J.; Wong, Y.-L.; Zeller, M.; Hunter, A.D.; Xu, Z. Pd Uptake and $\mathrm{H}_{2} \mathrm{~S}$ Sensing by an Amphoteric Metal-Organic Framework with a Soft Core and Rigid Side Arms. Angew. Chem. Int. Ed. 2014, 53, 14438-14442. [CrossRef]

22. Barrett, S.M.; Wang, C.; Lin, W. Oxygen Sensing via Phosphorescence Quenching of Doped Metal-Organic Frameworks. J. Mater. Chem. 2012, 22, 10329-10334. [CrossRef]

23. Xie, Z.; Ma, L.; deKrafft, K.E.; Jin, A.; Lin, W. Porous Phosphorescent Coordination Polymers for Oxygen Sensing. J. Am. Chem. Soc. 2010, 132, 922-923. [CrossRef] [PubMed]

24. Zhang, M.; Feng, G.; Song, Z.; Zhou, Y.P.; Chao, H.Y.; Yuan, D.; Tan, T.T.; Guo, Z.; Hu, Z.; Tang, B.Z.; et al. Two-Dimensional Metal-Organic Framework with Wide Channels and Responsive Turn-On Fluorescence for the Chemical Sensing of Volatile Organic Compounds. J. Am. Chem. Soc. 2014, 136, 7241-7244. [CrossRef] [PubMed]

25. Li, Y.; Zhang, S.; Song, D. A Luminescent Metal-Organic Framework as a Turn-On Sensor for DMF Vapor. Angew. Chem. Int. Ed. 2013, 52, 710-713. [CrossRef] 
26. Shustova, N.B.; McCarthy, B.D.; Dinca, M. Metal-Organic Frameworks: An Alternative to Aggregation-Induced Emission. J. Am. Chem. Soc. 2011, 133, 20126-20129. [CrossRef] [PubMed]

27. Hong, Y.; Lam, J.W.Y.; Tang, B.Z. Aggregation-Induced Emission. Chem. Soc. Rev. 2011, 40, 5361-5388. [CrossRef]

28. Zhao, S.S.; Yang, J.; Liu, Y.Y.; Ma, J.F. Fluorescent Aromatic Tag-Functionalized MOFs for Highly Selective Sensing of Metal Ions and Small Organic Molecules. Inorg. Chem. 2016, 55, 2261-2273. [CrossRef]

29. Shustova, N.B.; Cozzolino, A.F.; Reineke, S.; Baldo, M.; Dinca, M. Selective Turn-On Ammonia Sensing Enabled by High-Temperature Fluorescence in Metal-Organic Frameworks with Open Metal Sites. J. Am. Chem. Soc. 2013, 135, 13326-13329. [CrossRef]

30. Mallick, A.; Garai, B.; Addicoat, M.A.; Petkov, P.S.; Heine, T.; Banerjee, R. Solid State Organic Amine Detection in a Photochromic Porous Metal Organic Framework. Chem. Sci. 2015, 6, 1420-1425. [CrossRef]

31. Takashima, Y.; Martinez, V.M.; Furukawa, S.; Kondo, M.; Shimomura, S.; Uehara, H.; Nakahama, M.; Sugimoto, K.; Kitagawa, S. Molecular Decoding Using Luminescence from an Entangled Porous Framework. Nat. Commun. 2011, 2, 168. [CrossRef]

32. Stylianou, K.C.; Heck, R.; Chong, S.Y.; James, J.B.; Jones, T.A.; Khimyak, Y.Z.; Bradshaw, D.; Rosseinsky, M.J. A Guest-Responsive Fluorescent 3D Microporous Metal-Organic Framework Derived from a Long-Lifetime Pyrene Core. J. Am. Chem. Soc. 2010, 132, 4119-4130. [CrossRef] [PubMed]

33. Mukherjee, S.; Desai, A.V.; Manna, B.; Inamdar, A.I.; Ghosh, S.K. Exploitation of Guest Accessible Aliphatic Amine Functionality of a Metal-Organic Framework for Selective Detection of 2,4,6-Trinitrophenol (TNP) in Water. Cryst. Growth Des. 2015, 15, 4627-4634. [CrossRef]

34. Nagarkar, S.S.; Desai, A.V.; Samanta, P.; Ghosh, S.K. Aqueous Phase Selective Detection of 2,4,6-Trinitrophenol Using a Fluorescent Metal-Organic Framework with a Pendant Recognition Site. Dalton Trans. 2015, 44, 15175-15180. [CrossRef] [PubMed]

35. Guo, Y.; Feng, X.; Han, T.; Wang, S.; Lin, Z.; Dong, Y.; Wang, B. Tuning the Luminescence of Metal-Organic Frameworks for Detection of Energetic Heterocyclic Compounds. J. Am. Chem. Soc. 2014, 136, 15485-15488. [CrossRef] [PubMed]

36. Qin, L.; Lin, L.-X.; Fang, Z.-P.; Yang, S.-P.; Qiu, G.-H.; Chen, J.-X.; Chen, W.-H. A Water-Stable Metal-Organic Framework of a Zwitterionic Carboxylate with Dysprosium: A Sensing Platform for Ebolavirus RNA Sequences. Chem. Commun. 2016, 52, 132-135. [CrossRef]

37. Zhang, H.T.; Zhang, J.W.; Huang, G.; Du, Z.Y.; Jiang, H.L. An Amine-Functionalized Metal-Organic Framework as a Sensing Platform for DNA Detection. Chem. Commun. 2014, 50, 12069-12072. [CrossRef]

38. Zhang, S.-R.; Li, J.; Du, D.-Y.; Qin, J.-S.; Li, S.-L.; He, W.-W.; Su, Z.-M.; Lan, Y.-Q. A Multifunctional Microporous Anionic Metal-Organic Framework for Column-Chromatographic Dye Separation and Selective Detection and Adsorption of $\mathrm{Cr}^{3+}$. J. Mater. Chem. A 2015, 3, 23426-23434. [CrossRef]

39. Wang, Y.; Cheng, L.; Liu, Z.-Y.; Wang, X.-G.; Ding, B.; Yin, L.; Zhou, B.-B.; Li, M.-S.; Wang, J.-X.; Zhao, X.-J. An Ideal Detector Composed of Two-Dimensional Cd(II)-Triazole Frameworks for Nitro-Compound Explosives and Potassium Dichromate. Chem. Eur. J. 2015, 21, 14171-14178. [CrossRef]

40. Wu, P.; Liu, Y.; Liu, Y.; Wang, J.; Li, Y.; Liu, W.; Wang, J. Cadmium-Based Metal-Organic Framework as a Highly Selective and Sensitive Ratiometric Luminescent Sensor for Mercury(II). Inorg. Chem. 2015, 54, 11046-11048. [CrossRef]

41. Hao, J.-N.; Yan, B. A Water-Stable Lanthanide-Functionalized MOF as a Highly Selective and Sensitive Fluorescent Probe for $\mathrm{Cd}^{2+}$. Chem. Commun. 2015, 51, 7737-7740. [CrossRef]

42. Cui, L.; Wu, J.; Li, J.; Ju, H. Electrochemical Sensor for Lead Cation Sensitized with a DNA Functionalized Porphyrinic Metal-Organic Framework. Anal. Chem. 2015, 87, 10635-10641. [CrossRef] [PubMed]

43. Wang, Y.; Wu, Y.; Xie, J.; Hu, X. Metal-Organic Framework Modified Carbon Paste Electrode for Lead Sensor. Sens. Actuators B 2013, 177, 1161-1166. [CrossRef]

44. Tan, H.; Liu, B.; Chen, Y. Lanthanide Coordination Polymer Nanoparticles for Sensing of Mercury(II) by Photoinduced Electron Transfer. ACS Nano 2012, 6, 10505-10511. [CrossRef] [PubMed]

45. Ma, J.-P.; Yu, Y.; Dong, Y.-B. Fluorene-Based Cu(II)-MOF: A Visual Colorimetric Anion Sensor and Separator Based on an Anion-Exchange Approach. Chem. Commun. 2012, 48, 2946-2948. [CrossRef] [PubMed]

46. Chow, C.-F.; Lam, M.H.W.; Wong, W.-Y. A Heterobimetallic Ruthenium(II)-Copper(II) Donor-Acceptor Complex as a Chemodosimetric Ensemble for Selective Cyanide Detection. Inorg. Chem. 2004, 43, 8387-8393. [CrossRef] [PubMed] 
47. Robin, A.Y.; Fromm, K.M. Coordination Polymer Networks with O- And N-Donors: What They Are, Why and How They Are Made. Coord. Chem. Rev. 2006, 250, 2127-2157. [CrossRef]

48. Janiak, C. Engineering Coordination Polymers Towards Applications. Dalton Trans. 2003, 2781-2804. [CrossRef]

49. Esteves, C.I.C.; Silva, A.M.F.; Raposo, M.M.M.; Costa, S.P.G. Unnatural Benz-X-Azolyl Asparagine Derivatives as Novel Fluorescent Amino Acids: Synthesis and Photophysical Characterization. Tetrahedron 2009, 65, 9373-9377. [CrossRef]

50. Batista, R.M.F.; Costa, S.P.G.; Raposo, M.M.M. Synthesis of New Fluorescent 2-(2',2"-Bithienyl)-1,3-Benzothiazoles. Tetrahedron Lett. 2004, 45, 2825-2828. [CrossRef]

51. Lee, S.-H.; Otomo, A.; Nakahama, T.; Yamada, T.; Kamikado, T.; Yokoyama, S.; Mashiko, S. Novel Rigid-Rod 2,6-Diphenylbenzo[1,2- $\left.d: 4,5-d^{\prime}\right]$ Bisthiazole (DPBBT) Derivatives for Second-Order Nonlinear Optical Chromophores. J. Mater. Chem. 2002, 12, 2187-2188. [CrossRef]

52. Breitung, E.M.; Shu, C.-F.; McMahon, R.J. Thiazole and Thiophene Analogues of Donor-Acceptor Stilbenes: Molecular Hyperpolarizabilities and Structure-Property Relationships. J. Am. Chem. Soc. 2000, 122, 1154-1160. [CrossRef]

53. Sangiorgi, N.; Sangiorgi, A.; Dessì, A.; Zani, L.; Calamante, M.; Reginato, G.; Mordini, A.; Sanson, A. Improving the Efficiency Of Thin-Film Fiber-Shaped Dye-Sensitized Solar Cells By Using Organic Sensitizers. Sol. Energy Mater. Sol. Cells 2020, 204, 110209. [CrossRef]

54. Dessì, A.; Monai, M.; Bessi, M.; Montini, T.; Calamante, M.; Mordini, M.; Reginato, G.; Trono, C.; Fornasiero, P.; Zani, L. Towards Sustainable $\mathrm{H}_{2}$ Production: Rational Design of Hydrophobic Triphenylamine-based Dyes for Sensitized Ethanol Photoreforming. ChemSusChem 2018, 11, 793-805. [CrossRef] [PubMed]

55. Staderini, S.; Tuci, G.; Luconi, L.; Müller, P.; Kaskel, S.; Eychmüller, A.; Eichler, F.; Giambastiani, G.; Rossin, A. Zinc Coordination Polymers Containing Isomeric Forms of $p$-(Thiazolyl)benzoic Acid: Blue-Emitting Materials with a Solvatochromic Response to Water. Eur. J. Inorg. Chem. 2017, 4909-4918. [CrossRef]

56. Staderini, S.; Tuci, G.; D'Angelantonio, M.; Manoli, F.; Manet, I.; Giambastiani, G.; Peruzzini, M.; Rossin, A. Zinc Coordination Polymers Containing the $m$-(2-thiazolyl)benzoic Acid Spacer: Synthesis, Characterization and Luminescent Properties in Aqueous Solutions. ChemistrySelect 2016, 6, 1123-1131. [CrossRef]

57. Tuci, G.; Giambastiani, G.; Kwon, S.; Stair, P.C.; Snurr, R.Q.; Rossin, A. Chiral Co(II) Metal-Organic Framework in the Heterogeneous Catalytic Oxidation of Alkenes under Aerobic and Anaerobic Conditions. ACS Catal. 2014, 4, 1032-1039. [CrossRef]

58. Rossin, A.; Tuci, G.; Giambastiani, G.; Peruzzini, M. 1D and 2D Thiazole-Based Copper(II) Coordination Polymers: Synthesis and Applications in Carbon Dioxide Capture. ChemPlusChem 2014, 79, 406-412. [CrossRef]

59. Rossin, A.; Di Credico, B.; Giambastiani, G.; Peruzzini, A.; Pescitelli, G.; Reginato, G.; Borfecchia, E.; Gianolio, D.; Lamberti, C.; Bordiga, S. Synthesis, Characterization and $\mathrm{CO}_{2}$ Uptake of a Chiral $\mathrm{Co}(\mathrm{II})$ Metal-Organic Framework Containing a Thiazolidine-Based Spacer. J. Mater. Chem. 2012, 22, 10335-10344. [CrossRef]

60. Rossin, A.; Giambastiani, G. Structural Features and Applications of Metal-Organic Frameworks Containing Thiazole- and Thiazolidine-Based Spacers. CrystEngComm 2015, 17, 218-228. [CrossRef]

61. Dannenbauer, N.; Matthes, P.R.; Scheller, T.P.; Nitsch, J.; Zottnick, S.H.; Gernert, M.S.; Steffen, A.; Lambert, C.; Müller-Buschbaum, K. Near-Infrared Luminescence and Inner Filter Effects of Lanthanide Coordination Polymers with 1,2-Di(4-pyridyl)Ethylene. Inorg. Chem. 2015, 55, 7396-7406. [CrossRef]

62. Dannenbauer, N.; Matthes, P.R.; Müller-Buschbaum, K. Luminescent Coordination Polymers for the VIS and NIR Range Constituting $\mathrm{LnCl}_{3}$ and 1,2-Bis(4-Pyridyl)Ethane. Dalton Trans. 2016, 45, 6529-6540. [CrossRef] [PubMed]

63. Dannenbauer, N.; Zottnick, S.H.; Müller-Buschbaum, K. Thiazole and the Diazines Pyrazine and Pyrimidine as Sensitizers for Lanthanide Luminescence from VIS to NIR. Z. Anorg. Allg. Chem. 2017, 643, 1513-1518. [CrossRef]

64. Chen, M.; Sun, R.; Ye, Y.; Tang, H.; Dong, X.; Yan, J.; Wang, K.; Zhou, Q.; Wang, Z. Application of a Novel Red-Emitting Cationic Iridium(III) Coordination Polymer in Warm White Light-Emitting Diodes. Opt. Mater. 2018, 76, 141-146. [CrossRef]

65. Artem'ev, A.V.; Samsonenko, D.G.; Antonova, O.V. CuI-Based Coordination Polymers with 2-Thiazolyl Sulfide Ligands: First Examples. Polyhedron 2018, 151, 171-176. [CrossRef] 
66. Rogovoy, M.I.; Samsonenko, D.G.; Rakhmanova, M.I.; Artem'ev, A.V. Self-Assembly of Ag(I)-Based Complexes and Layered Coordination Polymers Bridged by (2-Thiazolyl)Sulfides. Inorg. Chim. Acta 2019, 489, 19-26. [CrossRef]

67. Woodward, A.N.; Kolesar, J.M.; Hall, S.R.; Saleh, N.; Jones, D.S.; Walter, M.G. Thiazolothiazole Fluorophores Exhibiting Strong Fluorescence and Viologen-Like Reversible Electrochromism. J. Am. Chem. Soc. 2017, 139, 8467-8473. [CrossRef]

68. Zhang, Z.; Chen, Y.; Hung, W.; Tang, W.; Hsu, Y.; Chen, C.; Meng, F.; Chou, P. Control of the Reversibility of Excited-State Intramolecular Proton Transfer (ESIPT) Reaction: Host-Polarity Tuning White Organic Light Emitting Diode on a New Thiazolo[5,4-d]thiazole ESIPT System. Chem. Mater. 2016, 23, 8815-8824. [CrossRef]

69. Dessì, A.; Calamante, M.; Mordini, A.; Peruzzini, M.; Sinicropi, A.; Basosi, R.; Fabrizi de Biani, F.; Taddei, M.; Colonna, D.; di Carlo, A.; et al. Organic Dyes with Intense Light Absorption Especially Suitable for Application in Thin-Layer Dye-Sensitized Solar Cells. Chem. Commun. 2014, 50, 13952-13955. [CrossRef]

70. Pereira Clementino, R.F.; de Souza Santos, A.B.; Bandeira Jovino Marques, O.J.; Ratkovski, D.R.; Gatto, C.C.; Malvestiti, I.; de Araujo Machado, F.L.; Lago Falcão, E.H. Structural Description, Luminescent and Magnetic Properties of Novel 2-D Coordination Polymers Containing Thiazolo[5,4- $d$ ]Thiazole Rings and Trivalent Lanthanide Ions. J. Solid State Chem. 2018, 268, 94-101. [CrossRef]

71. Zhai, Z.; Yang, S.; Cao, M.; Li, L.; Du, C.; Zang, S. Rational Design of Three Two-Fold Interpenetrated Metal-Organic Frameworks: Luminescent Zn/Cd-Metal-Organic Frameworks for Detection of 2,4,6-Trinitrophenol and Nitrofurazone in the Aqueous Phase. Cryst. Growth Des. 2018, 18, 7173-7182. [CrossRef]

72. Zhai, Z.; Yang, S.; Luo, P.; Li, L.; Du, C.; Zang, S. Dicarboxylate-Induced Structural Diversity of Luminescent $\mathrm{Zn}(\mathrm{II}) / \mathrm{Cd}(\mathrm{II})$ Metal-Organic Frameworks Based on the 2,5-Bis(4-Pyridyl)Thiazolo[5,4-d]Thiazole Ligand. Eur. J. Inorg. Chem. 2019, 2725-2734. [CrossRef]

73. Khatun, A.; Panda, D.K.; Sayresmith, N.; Walter, M.G.; Saha, S. Thiazolothiazole-Based Luminescent Metal-Organic Frameworks with Ligand-to-Ligand Energy Transfer and $\mathrm{Hg}^{2+}$ Sensing Capabilities. Inorg. Chem. 2019, 58, 12707-12715. [CrossRef] [PubMed]

74. Arici, M.; Yesilel, O.Z.; Dege, N. Three Co(II) Coordination Polymers Constructed from 2,5-Di(4-Pyridyl)Thiazolo[5,4- $d$ ]Thiazole and V-Shaped Dicarboxylic Acids: Syntheses, Characterizations, Structural Diversity and Optical Properties. Polyhedron 2019, 163, 77-83. [CrossRef]

75. Li, P.; Yin, X.; Gao, L.; Yang, S.; Sui, Q.; Gong, T.; Gao, E. Modulating Excitation Energy of Luminescent Metal-Organic Frameworks for Detection of Cr(VI) in Water. ACS Appl. Nano Mater. 2019, 2, 4646-4654. [CrossRef]

76. Fan, J.; Li, J.; Zhang, L.; Zhang, L.; Wang, D. New Cu ${ }^{\mathrm{II}}$ and Cd $\mathrm{CI}^{\mathrm{II}}$ Metal-organic Coordination Polymers with 1,2,4-Triazolo[3,4-b]-1,3,4-Thiadiazole Ligands: Syntheses, Structures and Luminescent Properties. J. Chin. Chem. Soc. 2015, 62, 786-792. [CrossRef]

77. Wen, G.; Liu, D.; Chen, Y.; Wei, Y.; Zhu, Q.; Wang, X.; Xua, M.; Yao, Y.; Ma, L. A Rare Twofold Interpenetrating $\mathrm{NbO}$ Mixed-Ligand Mesomeric Network from Two Individual Heterochiral 3D Frameworks. Inorg. Chem. Commun. 2016, 74, 86-89. [CrossRef]

78. Zhang, X.; Zhang, X.; Fan, C.; Zong, Z.; Zhang, D.; Luo, Q.; Bi, C.; Fan, Y. A Novel Metal-Organic Frameworks Assembled by One Angular Ligand and 5-Aminoisophthalic Acid: Synthesis, Structure, Electrochemical and Photocatalytic Properties. Polyhedron 2019, 168, 21-27. [CrossRef]

79. Sk, M.; Biswas, S. A Thiadiazole-Functionalized Zr(IV)-Based Metal-Organic Framework as a Highly Fluorescent Probe for the Selective Detection of Picric Acid. CrystEngComm 2016, 18, 3104-3113. [CrossRef]

80. Mallick, A.; El-Zohry, A.M.; Shekhah, O.; Yin, J.; Jia, J.; Himanshu Aggarwal, H.; Emwas, A.; Mohammed, O.F.; Eddaoudi, M. Unprecedented Ultralow Detection Limit of Amines using a Thiadiazole-Functionalized Zr(IV)-Based Metal-Organic Framework. J. Am. Chem. Soc. 2019, 141, 7245-7249. [CrossRef]

81. Song, W.; Liang, L.; Cui, X.; Wang, X.; Yang, E.; Zhao, X. Assembly of Zn ${ }^{\text {II }-C o o r d i n a t i o n ~ P o l y m e r s ~}$ Constructed from Benzothiadiazole Functionalized Bipyridines and V-Shaped Dicarboxylic Acids: Topology Variety, Photochemical and Visible-Light-Driven Photocatalytic Properties. CrystEngComm 2018, 20, 668-678. [CrossRef] 
82. Wang, X.; Xiong, Y.; Sha, X.; Liu, G.; Lin, H. Various Polycarboxylate-Directed Cd(II) Coordination Polymers Based on a Semirigid Bis-Pyridyl-bis-Amide Ligand: Construction and Fluorescent and Photocatalytic Properties. Cryst. Growth Des. 2017, 17, 483-496. [CrossRef]

83. Gogia, A.; Mandal, S.K. A Rational Design and Green Synthesis of 3D Metal Organic Frameworks Containing a Rigid Heterocyclic Nitrogen-Rich Dicarboxylate: Structural Diversity, $\mathrm{CO}_{2}$ Sorption and Selective Sensing of 2,4,6-TNP in Water. Dalton Trans. 2019, 48, 2388-2398. [CrossRef] [PubMed]

84. Müller, P.; Bucior, B.; Tuci, G.; Luconi, L.; Getzschmann, J.; Kaskel, S.; Snurr, R.Q.; Giambastiani, G.; Rossin, A. Computational Screening, Synthesis and Testing of Metal-Organic Frameworks with a Bithiazole Linker for Carbon Dioxide Capture and its Green Conversion into Cyclic Carbonates. Mol. Syst. Des. Eng. 2019, 4, 1000-1013. [CrossRef]

(C) 2019 by the authors. Licensee MDPI, Basel, Switzerland. This article is an open access article distributed under the terms and conditions of the Creative Commons Attribution (CC BY) license (http://creativecommons.org/licenses/by/4.0/). 